\title{
Destin și subdestin în romanele lui Marin Preda
}

\author{
Drd. MARCU Ovidiu \\ Universitatea „Dunărea de Jos” din Galați
}

\begin{abstract}
The characters in Marin Preda's novels are anchored in the objective history of the time they live in and become victims of circumstances that brutally transform their existence, canceling their natural right to happiness, after they had been left with the illusion that they were favoured by destiny itself. Călin Surupăceanu, the protagonist of the novel "The Intruder" and Victor Petrini, the main character of the novel "The most beloved man on Earth", go through ecstasy down to agony, being forced by circumstances, at a time when nothing predicts the existential collapse. The way these characters which cross different records of existence are built projects them into a tragic dimension. Preda proves to be the partisan of the thinking one can encounter during the Greek antiquity, according to which man is twice guilty: once against the gods (a mistake they call "hamartia") and secondly against his fellows through "hybris"(the unmeasured pride that darkens his reason). As a consequence of these errors, man must be subjected to a life and death experience in order to purify by suffering his high consciousness and in order for him to acquire, after the recognition of moral guilt, total wisdom and perfect contemplation, having access to the tragic metaphysical.
\end{abstract}

Keywords: destiny, subdestiny, life and death experiences, moral guilt, tragic, metaphysical

Personajele din romanele lui Marin Preda sunt ancorate în istoria concretă a timpului pe care îl trăiesc și devin victime ale circumstanțelor care le transformă în mod brutal existența, anulându-le dreptul la fericire, după ce le lăsase iluzia că sunt în grațiile destinului. Călin Surupăceanu, protagonistul romanului "Intrusul" și Victor Petrini, eroul romanului "Cel mai iubit dintre pământeni" traversează, forțați de împrejurări care le schimbă radical viața, drumul de la extaz la agonie în momente în care nimic nu anticipa prăbușirea ființială.

Modalitatea în care sunt construite aceste personaje care traversează registre diferite de existență le proiectează într-o dimensiune tragică. Preda se dovedește adeptul gândirii întâlnite în antichitatea greacă, conform căreia omul 
este de două ori vinovat: o dată față de zei (greșeală pe care o numesc "hamartia") și apoi față de semenii lui (prin "hybris", trufia nemăsurată care îi întunecă rațiunea). Ca urmare a acestor erori, omul trebuie să fie supus unor experiențe- limită, care să-1 purifice prin suferință conștiința superioară și să dobândească, după recunoașterea vinei morale, înțelepciunea și contemplația având acces la tragicul metafizic.

Destinul celor două personaje, Călin Surupăceanu și Victor Petrini se modifică radical, după ce "pățesc" ceva, un verb recurent în scrierile lui Preda, prin care exprimă experiența-limită care le marchează definitiv existența. Desfigurarea sau stigmatul fizic în cazul lui Călin Surupăceanu devine un semn al unui om marcat pe tot restul vieții. Stigmatul marchează involuția personajului, care pierde, în urma unui accident banal, totul: familia, prietenii, locul de muncă. Pentru Victor Petrini decăderea sau stigmatul moral exprimă (indică) semnul prăbușirii morale în ochii celorlalți: familia, reprezentată de tatăl ce se simte dezonorat și-l condamnă pentru involuție; soția, Matilda, care-1 părăsește pentru că nu concepea că soțul arhitectei lucrează la deratizare; prietenul, Ion $\mathrm{Micu}$, universitarul care se dezice de valorile prieteniei.

Aparent fără nicio legătură între ele, personajele plasate în medii sociale diferite, acceptă provocarea destinului sau îl provoacă ori sunt provocate de acesta fără să poată refuza jocul de-a viața, chiar dacă la sfârșitul jocului după reguli nescrise sunt victime ale hazardului, care le joacă o farsă cu urmări nefaste. Inițial, Surupăceanu este vopsitor și își petrece cea mai mare parte a timpului de lucru pe turlele bisericilor sau pe acoperișurile caselor, aproape de cer și liber de constrângerile existenței, o ipostază modernă a mitului lui Icar. Chiar dacă lucrează la înălțimi amețitoare, Surupăceanu sfidează destinul, pentru că nu simte, nici atunci când se apropie de streașina acoperișului, teama de prăbușire. Dimpotrivă, lumea privită de sus îi oferă sentimentul măreției și satisfacția muncii sub lumina protectoare a zilei.

Privind retrospectiv acea perioadă fericită, Surupăceanu constată că a fost un protejat al sorții, pentru că își cunoștea limitele și asculta vocea conștiinței și pe cea a meșterului lângă care lucra: "... mi-e greu să văd de ce aş fi putut fi atât de vesel, cu atât mai mult cu cât meșterul cu care lucram mă înjura să tac din gură și să fiu atent să nu-mi alunece cumva piciorul și să cad, fiindcă pilaf mă fac când o să ajung jos... În realitate de atunci și până... m-am uitat totdeauna curios în hăul care se căsca sub picioarele mele, mă miram cum lucrurile se făceau mici și ce întins și gros era pământul văzut de la înălțime."281

${ }^{281}$ Marin Preda Opere, vol. II, Editura Univers enciclopedic, București, 2002, p. 108. 
Momentul de rupere a echilibrului interior îl constituie pentru Călin Surupăceanu întâlnirea cu inginerul Dan, cel care îi revelează posibilitatea de ași depăși limitele de a provoca destinul, prin eliberarea de statutul umil de vopsitor și acceptarea celui de constructor, de făuritor al unei lumi noi. Este momentul în care Călin, provocând destinul, provoacă hybrisul, adică acea depășire a măsurii în relația dintre om și forțele superioare lui.

Prin intermediul inginerului Dan, care reprezintă vocea rațiunii, Călin ascultă vocea orgoliului nemăsurat de a contribui la schimbarea lumii, la (re)construirea ei din temelii. În tragedia greacă, hamartia "greșeala", constituie alături de hybris una dintre cauzele prăbușirii eroului tragic, echivalând cu o sentință ce urmează să se îndeplinească în chip fatal. Pentru Călin, hamartia este reprezentată de convingerea că, acceptând să devină constructor, devine implicit creator, substituindu-se Divinității. În chemarea inginerului el identifică chemarea Moirelor și consideră că mesajul acestuia echivalează cu marea chemare a vieții: "Aruncă bidineaua, ia-ți ziua bună de la frați și surori și vino cu mine să construim o altă lume, fiindcă asta în care am trăit până acum nu e bună. Nu e nevoie să știi tu de ce, dar ce trebuie să știi neaparat e că ăsta e ceasul tău cel nou, dacă $̂ l$ scapi nu e numai că ai să rămâi un om care nu știe nimic, dar o să se uite toți de seama ta la tine ca la cel mai prost dintre ei și partea interesantă o să fie că n-o să ai ce să le răspunzi. Nu lor, a strigat acest domn când a ajuns cu vorbele lui până aici, ție n-o să ai ce să-ți răspunzi, că ți s-a ivit ocazia și ai scăpat-o și că ai fost chemat să construiești o lume nouă și ai fugit pe acoperiș"282

Chemarea inginerului Dan îmbracă tonul biblic al chemării apostolilor pentru că solicită renunțarea totală la lumea veche și la viața de până atunci și acceptarea necondiționată a misiunii de a participa la construirea unei lumi noi într-un apostolat ce are la temelie idealul omului nou. Însă, spre deosebire de chemarea biblică a apostolilor pentru metamorfozarea lumii prin religia iubirii, lumea omului nou propusă de inginer are ca fundament religia urii care trimite la ura dintre clasele sociale, ce modifică la rândul ei destinele aruncate în malaxorul existenței.

Victimă a noii religii, Victor Petrini este ipostaza intelectualului provocat de destin după un algoritm al hazardului, care se dovedește că i-a jucat o farsă, transformându-1 într-o jucărie a sorții. În urma acestui joc, Petrini parcurge drumul invers și trece prin două condamnări, politică și civilă, care înving rezistența fizică a omului, nu și pe cea spirituală, prin intermediul căruia triumfă.

${ }_{282}$ Marin Preda, Opere, vol. II, Editura Univers enciclopedic, București, 2002, p. 128. 
Cele două condamnări intervin în momente în care protagonistul se credea ancorat în realitatea trăită a sentimentului de împlinire prin întregirea familiei (căsătoria cu Matilda și nașterea fetiței) și regăsirea sufletului pereche, care să ofere certitudinea iubirii (relația cu Suzy). Cearta (confruntarea) violentă a soților Petrini la petrecerea organizată după botez,culminând cu violența fizică sub privirile stupefiate ale rudelor constituie doar preambulul dezlănțuirii destinului nemilos. În concepția antichității,fatum reprezintă forța suverană "care hotărăşte ursita fiecăruia și căruia trebuie să $i$ se supună chiar Jupiter" 283 , întrucât acționează asupra omului asemenea stihiilor. Apariția bruscă a celor trei ofițeri de securitate care pătrund cu brutalitate în locuința familiei Petrini întruchipează manifestarea concretă a fatumului, forța oarbă a imprevizibilului.

Arestarea și acuzarea lui Victor Petrini sub pretextul colaboraționalismului cu organizația teroristă Sumanele negre apare ca o împlinire a fatumului care refuză prin mesagerii ei eludarea confuziei lingvistice între lexemele "ordine" și "ordonanță" din scrisoarea expediată de un fost coleg de facultate, Iustin Comănescu. Pentru ofițerii de Securitate, scrisoarea este un document încifrat, prin care asistentul universitar Petrini dă ordine camarazilor din străinătate și pune în pericol siguranța țării. În viziunea colonelului vinovăția universitarului este categorică și nu poate fi combătută prin argumente: "Asta e scrisoare cu cifru, strigă colonelul și mă uitai uluit la expresia chipului său pe care apăruse o liniștită convingere: aștept ordinele dumneavoastră! "Ordonanțele", repetai și eu liniștit și ferm. Tot aia e! zise. Nu e tot aia! V-am explicat." 284

Suspiciunea care planează asupra lui Petrini dobândește caracter sentențial și îl trimite pentru trei ani, întâi la muncă forțată la Canal, și apoi în minele de plumb de la Baia Sprie, pentru o vină fictivă, deturnându-1 de la cariera universitară către lumea subterană a închisorii. Coborârea sau prăbușirea devine o formă de regresie fizică sau morală, o modalitate de culpabilizare de către societate, care îi refuză protagonistului dreptul la fericire.

Aspirand la o carieră universitară fericită și la crearea unui sistem filozofic propriu, bazat pe o credință rațională, prin care să înlocuiască dogma, Petrini devine o victimă a destinului orb pentru că a pierdut echilibrul și simțul măsurii. Pentru vechii greci, măsura era mai presus decât toate lucrurile de sub soare și constituia izvorul unei vieți fericite prin cumpătare și dreptate. Trufia,

${ }^{283}$ Emil Boldan (coord), Dicționar de terminologie literară, Editura Științifică, București, 1970, p. 140.

${ }^{284}$ Marin Preda, Opere, vol. III, Editura Univers enciclopedic, București, 2012, p. 914. 
hybrisul sunt pedepsite de Divinitate și conduc spre prăbușirea celui care s-a făcut vinovat. În concepția grecilor din primele veacuri, hybrisul numește deopotrivă trufia eroului tragic, cât și crima generată de acesta."285

Condamnarea lui Victor Petrini constituie o formă de manifestare a hybrisului și configurează un traseu existențial în care personajul parcurge treptele decăderii. Dacă înainte de arestare, Petrini se bucura de privilegiile oferite de statutul social și de respectul primit din partea studenților, după pierderea libertății își pierde și identitatea pentru că devine un număr, 1003, ipostază a depersonalizării și singura modalitate de identificare în existența închisorii.

Închisoarea, mai ales cea pentru deținuții politici în care este încarcerat, îl confruntă pe Victor Petrini cu o lume pestriță al cărei singur scop îl reprezintă evidențierea instinctului de supraviețuire. Ca metaforă a recluziunii subterana, primește mai multe accepții: spațiu al detenției, cu forma cea mai agresivă carcera, mina, imagine a grotei și a instinctelor primare, dar și spațiu thanatic, ca o variantă inversată a pântecului matern. Conform DEX, subterana este un spațiu "care se află la o adâncime oarecare sub suprafața pământului; încăpere, galerie, construcție aflată în întregime( la adâncime mare)sub pământ."286

Imagine a unui destin frânt, metafora subteranei primește pentru personajul predist două accepții: în mină, printre deținuți este o formă prin care agresivitatea mediului se transferă asupra oamenilor; după eliberare, în subsolurile insalubre, printre șobolani, evidențiază transferul de comportament prin agresivitatea omului și umanizarea animalului vânat.

Trimis în mină pentru reeducare și tratat ca un dușman de clasă al poporului, Petrini parcurge, prin simbolismul minei un drum către sine, o întoarcere ontologică spre originile ființei. El traversează prin penitență o formă de regenerare spirituală și învață să distingă, în urma unei pedagogii dure, binele de rău. Din acest motiv condamnarea la muncă silnică și coborârea zilnică în mină poate fi considerată o a doua naștere. Ca intelectual, Petrini judeca lumea prin spectrul rațiunii, ca deținut și mai ales după eliberare, el o privește în latura ei spirituală, fiindcă este umanizat prin suferință. Nu întâmplător, în Dicționarul de simboluri, coordonat de Jean Chevalier și Alain Gheerbrant,

${ }^{285}$ Emil Boldan (coord), Dicționar de terminologie literară, Editura Științifică, București, 1970, p. 167

286 *** Dicționarul explicativ al limbii române, Editura Univers enciclopedic, București,1996, p. 1035. 
mina este asociată cu matricea: "Minele sunt și ele matrice din care se extrag cu metode raportate la obstetrică, minereurile embrionare care s-au maturat acolo." 287

În perioada de detenție Victor Petrini este pus, asemenea personajelor din tragedia greacă, în situații limită, fiind nevoit să ucidă un gardian care își propusese să-l extermine prin trimiterea în fiecare noapte la carceră. Este momentul în care Petrini se află într-o dublă captivitate, asemenea personajului sorescian Iona după ce balena în care se afla este înghițită de alta. Carcera devine pentru fostul asistent universitar forma extremă a temniței, în care gardianul îl aruncase pentru a-1 anula spiritual. Strigătul disperat al lui Iona: "Mamă, mi s-a întâmplat o mare nenorocire! Mai naște-mă o dată!"288 își găsește corespondent în meditația lui Petrini din carcera: "Ei bine, îmi spusei, cu o hotărâre mai rece decât frigul care mă învăluie, n-o să mor, în schimb o să te omor eu pe tine. Dacă nu cumva mi-i scris să mor totuși eu și tu să trăiești și să înforești mai departe. Să vedem!"289

Omorându-1 pe gardianul care voia să-l elimine, Victor Petrini comite o greșeală care antrenează deznodământul fatal, numit de vechii greci hamartia .Această greșeală ce se consumă în plan uman are consecințe în evoluția personajului, care, deși pe moment se salvează în plan fizic, poartă în plan moral povara crimei pentru care nu poate invoca legitima apărare. În termenii de libertate și necesitate, Petrini acționează după conceptul răului involuntar din teologia pauliană (Sfântul Apostol Pavel): "Nu fac binele pe care-l vreau, ci răul pe care nu-l vreau, pe acela îl săvârșesc." 290

Noțiunile de rău și bine dobândesc în cazul lui Călin Surupăceanu alte semnificații, după cele două voci pe care protagonistul le ascultă sau este nevoit să le audă: vocea comunității, al cărui mesager este Maria, soția lui, și vocea conștiinței care-i dictează să acționeze pentru a salva viața unui camarad aflat în pericol de moarte. Gestul salvator al lui Surupăceanu este judecat de comunitate și privit ca un gest gratuit, prin faptul că muncitorul căzut în cisternă era un individ vicios, adică un om condamnat de viciu să stea la periferia societății. Lui Călin Surupăceanu, comunitatea, prin vocea soției, îi refuză statutul de erou pentru că gestul lui nu era considerat necesar.Hamartia, greșeala pe care o

${ }^{287}$ Jean Chevalier, Alain Gheerbrant (coord), Dicționar de simboluri, vol. II, Editura Artermis, București, 1995, p. 278

${ }_{288}$ Marin Sorescu, Iona, Editura Fundației „Marin Sorescu”, București, 2000, p. 39

${ }_{289}$ Marin Preda, Opere, vol. III, Editura Univers enciclopedic, București, 2012, p. 972

290 *** Biblia, Editura Litera, București, 2011, cu ilustrații,Epistola Sfântului Apostol Pavel către Romani, cap. VII, p. 2420 
săvărșește, îl îndepărtează treptat de familie și de prieteni, pentru că intervenția lui salvatoare are repercusiuni asupra fizionomiei și a capacității de a lucra.

Pentru Călin Surupăceanu cisterna în care coboară este o altă ipostază a subteranei, prin intermediul căreia cunoaște condiția însinguratului. Versiune a uterului matern, subterana are în acest caz efecte adverse pentru că marchează fizic trecerea lui Călin prin acest spațiu. Coborârea în cisternă devine o cathabază în sensul prăbușirii fizice, întrucât după acest moment Surupăceanu este un alt om, nu în sensul renașterii spirituale, ci al desfigurăriii, al mutilării fizice. Ieșirea la suprafață (anabază) se produce cu ajutorul celor din jur care asistă neputincioși la tragedia lui Surupăceanu. Explozia care se produce în cisternă îi lasă arsuri pe față și pe mâini, transformându-l dintr-un idealist într-o victimă a destinului. În cazul lui, elementul piric nu funcționează ca un element purificator, ci ca unul care-l condamnă la umilințe permanente: "Cineva mi-a scos batista care luase foc pe obrazul și pe gura mea și atunci am simțit că sunt ars, parcă sar fi smuls de pe chipul meu coaja unei răni vii." 291

După teribilul accident stigmatul fizic apare ca o împlinire a fatumului, divinitate a destinului în mitologia romană. În "Dicționar de mitologie greacă și romană" Pierre Grimal consideră că fatum, zeul destinului este în strânsă legătură cu rădăcina verbului "a vorbi" care "desemna cuvântul unui Zeu și, ca atare, se referea la o decizie divină irevocabilă." ${ }^{292}$. Această rostire profetică a zeului aduce cu sine ideea de fatalitate căreia îi este victimă Călin Surupăceanu. De altfel, numele personajului Surupăceanu provine de la verbul "a surpa" care acoperă atât sensurile a se dărâma, a se nărui, cât și variantele a răsturna pe cineva dintr-o situație privilegiată, a desființa, a nimici. Toate sensurile acestui verb acoperă direct sau indirect aspecte care țin de psihologia lui Călin Surupăceanu, întrucât viața și aspirațiile lui se năruie în urma accidentului, răutatea comunității îl desființează ca om, iar decizia soției de a-l părăsi îi nimicește încrederea în sprijinul familiei.

Dintr-un om călit, puternic, obișnuit să înfrunte și să sfideze primejdiile, Călin ajunge un individ golit de idealuri, incapabil să mai profeseze datorită sechelelor cu care rămâne după experiența traumatizantă a unui gest care s-a dorit nobil, dar care a fost asociat cu gest iresponsabil de către locuitorii orașului care l-au transformat într-un antierou. Onomastica personajului, Călin Surupăceanu, conține, așadar, prin prenume și nume o

${ }^{291}$ Marin Preda, Opere, vol. II, Editura Univers enciclopedic, București, 2002, p. 1187

292 Pierre Grimal, Dicționar de mitologie greacă și romană, Editura Saeculum I. O., București, 2003, p. 186 
ipostază a dualității ființei umane, coincidentia oppositorum despre care vorbeau latinii. Prin aceasta el amintește de Ianus Bifrons, zeu din mitologia latină, venerat inițial ca personificare divină a oricărui început și sfârșit, a oricărei intrări și ieșiri din case particulare sau clădiri publice romane.

Destinul promițător al lui Călin Surupăceanu se schimbă în totalitate în urma gestului sacrificial și îi oferă posibilitatea unor introspecții de natură existențială. După despărțirea de Maria, Călin meditează, pornind de la erezia bogumilică a frăției dintre bine și rău, dintre Dumnezeu și Satan, la noțiunile de destin și subdestin. Subdestinul este cel care te pune în situația de a distruge ceva în anumite împrejurări, deși ți-a fost dat să creezi.

Dilema existențială a lui Călin Surupăceanu este legată de opțiunea dintre bine și rău care bulversează ființa umană, iar termenii acestei dileme revin obsedant în psihologia personajelor prediste care își analizează viața: "Dacă în loc de bine și rău ziceam creație și distrugere, nu mai e nicio îndoială că răspunsul e afirmativ și ce ne rămâne de făcut e să nu ne greșim viața.Cum apărea viața mea ?Unde era greșeala ?Căci destinul nu e o asigurare.Mie îmi place să creez, nu să distrug, dar există un subdestin, care te poate vârî în împrejurări unde vei distruge, deși ți-a fost dat creezi.Acest subdestin micșorează forța fatalității celei mari asupra noastră, dar în egală măsură în bine ca și în rău, încât cuceririle noastre în acest sens poartă pecetea responsabilității noastre depline, nu mai putem învinui pe nimeni, nici pe noi înșine, și nu ne rămâne decât să devenim o întruchipare a suferinței fără ieșire, disperate, care $n$-are soluție nici în moarte. Iată, ce ne ferește de sinucidere în masă sau in lanţ." 293

În viziunea lui Marin Preda, subdestinul este condiționat de fatalitatea care acționează imperturbabil asupra sorții și generează suferință fizică sau psihică ale cărei cauze se află în problemele de conștiință: "Blestematele chestiuni insolubile" cum le numește autorul, acestea scindează ființa umană, care devine ca în textele dostoievskiene, un teritoriu de luptă între virtute și păcat. De altfel, privit din această perspectivă, subdestinul amintește de conceptul de predestinare, terminologie religioasă prin care conduita morală a omului este predeterminată pentru eternitate din voința divinității, iar faptele sale determină în egală măsură mîntuirea și pedeapsa pentru păcat. Dacă în antichitate, conceptul de predestinare se aplica atât oamenilor cât și zeilor, iar pentru greci cele trei Moire urmăreau destinul global, ulterior noțiunea devine fundamentală în creștinism unde este armonizată cu ideea de liber arbitru.

${ }^{293}$ Marin Preda, Opere, vol. II, Editura Univers enciclopedic, București, 2002, p. 1257 
După experiențele prin care trec și care le modifică viața, Călin Surupăceanu și Victor Petrini, constată că rămân singuri în fața suferinței fiindcă Maria și Matilda, soțiile lor, nu acceptă lângă ele bărbații cărora subdestinul le-a deviat traseul inițial al unui destin deosebit . Despărțirea de Maria și accidentul sunt analizate de Surupăceanu prin prisma subdestinului, încercând să găsească răspunsul la întrebarea dacă trebuia sau nu să se căsătorească: "Dacă răspund că am făcut o greșeală căsătorindu-mă, înseamnă că trebuia să mă resemnez încă de pe atunci cu ideea că până la sfârșitul vieții voi trăi singur, idee cu care nu sunt în stare să mă împac nici în prezent,în fața eșecului, darămite atunci în fața iubirii care mă orbea, iubire care în cele din urmă a eliminat și ideea alegerii. Alegerea era bine făcută. Atunci? Viața mea era, cumva, clădită nu pe creație, ci pe distrugere și am fost o victimă printre altele? Altele care? Inginerul Dan? Și mai care? Intregul oraș își vede de existența lui fără să ia în seamă un număr atât de mic de victime, ca să observe că există în ele, pentru el, vreo semnificație oarecare."294

Subterana ca metaforă a subdestinului continuă să îl urmărească pe Victor Petrini după ispășirea condamnării politice, fiindcă rămâne captiv într-un sistem totalitar care îi refuză reabilitarea trimițându-l la munca de jos într-o echipă de deratizare. Exterminarea șobolanilor din subsolurile insalubre ale instituțiilor sau ale imobilelor este o confirmare a faptului că personajul este considerat un veșnic condamnat, obligat să trăiască în permanență la raportarea victimă-călău. Captivitatea lui Petrini amintește de destinul lui Iov din textul omonim al Vechiului Testament.

Constrângerea individului ca modalitate de anulare a spiritului anihilează în același timp posibilitatea de opțiune pentru cel prins în menghina unor forțe oarbe cu caracter distinctiv asupra personalității. Lui Victor Petrini nu i se refuză doar dreptul firesc de reangajare în învățământul superior, acolo de unde fusese smuls printr-o farsă a destinului, dar i se interzice chiar să-i învețe abecedarul pe copii, formă elementară de educație, deși în închisoare fusese el însuși victimă a reeducării forțate.Ca jucărie în mâna destinului lui Petrini i se oferă ca singură posibilitate de angajare aceea de simplu muncitor în echipa de deratizare a orașului pentru a putea reflecta la treptele decăderii umane: "Surâdeam în sinea mea. Bietul Petrini, de care râsesem când îmi vorbise cu atâta patimă despre L'Avenir de Intelligence! Viziunea lui și a lui Maurras era idilică, nu la coadă aveam să fim puși, ci jos de tot, la deratizare. Simțeam un fel de bucurie, era a orgoliului de a disprețui până în adâncul ființei mele." 295

${ }^{294}$ Marin Preda, Opere, vol. II, Editura Univers enciclopedic, București, 2002, p.1257

${ }^{295}$ Marin Preda, Opere, vol. III, Editura Univers enciclopedic, București, 2012, p. 979-980 
Acceptând constrângerea din partea societății care refuză reintegrarea lui Petrini în societate, acesta acceptă prin slujba umilă oferită statutul de înfrânt. Înfrângerea lui Petrini se produce concomitent în cele două dimensiuni: profesională și sentimentală. În plan profesional fostul asistent universitar este aruncat de subdestin într-o spirală a involuției care îi ține spiritul captiv și îi limitează orizontul de așteptare. Subterana ca metaforă a eșecului îl direcționează pe Victor Petrini pe traseul reconversiei profesionale ca formă de regenerare morală prin asumarea greșelilor ipotetice. Ca lucrător la deratizare, apoi la spații verzi, urmând ciclul reintegrării ca strungar într-o uzină și încheind spirala profesională în calitate de contabil la ORACA, individului i se impune viziunea sistemului totalitar calea de atingere a catharsisului. Însă spre deosebire de accepția termenului în filozofia aristotelică, noțiunea de catharsis se contaminează pentru personajul predist cu sensul dat de pitagoreici, de vindecare prin purgare, de trecere printr-un purgatoriu ființial .

Pentru vechii greci, catharsisul constituia mijlocul de ușurare purificatoare, de purificare sufletească a spectatorilor de orice pasiune, de orice atașament la contingent. După Aristotel, catharsisul, stârnind mila și frica, săvârșește purificarea caracteristică acestor emoții și conduce la izgonirea răului din suflet, întocmai cum face arta medicală cu corpul. La sfârșitul acestei experiențe spirituale spectatorul trebuia să fie capabil să atingă metanoia, adică înnoirea minții. În sens strict etimologic metanoia se referă la penitență, ca manifestare a regretului pentru faptele făcute, însă a dobândit cu timpul sensul de schimbare morală a atitudinii față de propriile fapte.

Petrini este aspirat de subdestin într-o spirală profesională a involuției și trecut printr-un catharsis în sens purgatorial la capătul căruia nu întâlnește metanoia, ci un alt purgatoriu în care componenta profesională a protagonistului se întâlnește cu dimensiunea sentimentală a existenței. Dacă în momentul arestării lui, Victor Petrini trăia cu sentimentul că se poate salva prin împlinirea aspirației la o carieră universitară care să echilibreze criza conjugală alături de Matilda, ulterior, după eliberare aceasta nu poate accepta ideea că este soția unui individ căzut social și profesional, ajuns muncitor la deratizare. Dialogul privirilor exprimă elocvent ruptura cuplului și implicit abandonarea de sine în voia destinului: "Așadar ,acolo ajunsesem. O apăsai și eu cu privirea: da, acolo! Așadar arhitecta Matilda era soția unui individ numit Petrini, care lucra la serviciul de deratizare al orașului? Da! Putea intra și în blocul dumitale să-l vezi cu vermorelul în spate? Da, ăsta era soțul tău, tatăl fetiței tale, puteai să te trezești cu el în blocul unei prietene care să-l contemple lung și să povestească apoi și altora cum arată. 
Și mai vrei să trăiești cu mine, să te culci în patul meu și să mai stai să mănânci cu mine la masă? Nu, nu neapărat,n-o să mă agăț de nimeni..." 296

Încercând să schimbe lumea inflamată de aberațiile politicului, Victor Petrini construiește un sistem filozofic prin care își propune să schimbe criteriile de raportare la societate (factorul extern) însă, după arestare și condamnare, lumea interioară a gânditorului (filozofului) se prăbușește, sub efectul destinului influențat de alții.

În cazul lui Călin Surupăceanu, umilința inițială prin profesia considerată înjositoare de către inginerul Dan îl transformă în finalul experienței trăite într-un intrus respins de locuitorii orașului pe care l-a construit din temelii ca un Amfion modern. El este o victimă a subdestinului pentru că, deși are vocația de constructor al citadelei distruge inconștient chiar de la temelii edificiul căminului conjugal. Călin construiește în exterior dar nu reușește să fie constructorul de sine. El involuează dinspre condiția de om liber înspre aceea încorsetată de prejudecățile semenilor care îi refuză statutul de salvator.

Pentru ambele personaje după producerea evenimentului care are drept consecințe apariția stigmatului fizic sau a celui moral, întoarcerea la statutul inițial este imposibilă pentru că li se refuză reabilitarea. Consecința acestui fapt este că personajele prediste care poartă stigmatul stau sub semnul degradării, al eșecului profesional și sentimental, care le conferă o dimensiune tragică, chiar dacă reușesc să supraviețuiască experiențelor-limită, pentru că, în viziunea autorului "Omul nu este făcut să fie înfrânt."

${ }^{296}$ Marin Preda, Opere, vol. III, Editura Univers enciclopedic, București, 2012, p. 10041005 


\section{Bibliografie:}

*** Biblia, Editura Litera, București, 2011

*** Dicționarul explicativ al limbii române, Editura Univers enciclopedic, București, 1996

Boldan, Emil (coord.), Dicționar de terminologie literară, Editura Științifică, București, 1970

Chevalier, Jean; Gheerbrant, Alain, Dicționar de simboluri, vol. II, Editura Artermis, București, 1995

Grimal, Pierre, Dicționar de mitologie greacă și romană, Editura Saeculum I. O., București, 2003

\section{Corpus}

Preda, Marin, Opere, vol. II, Editura Univers enciclopedic, București, 2002

Preda, Marin, Opere, vol. III, Editura Univers enciclopedic, București, 2012

Sorescu, Marin, Iona, Editura Fundației „Marin Sorescu”, București, 2000 